\title{
충ำ稿文
}

\section{診療放射線技師定年退職後の二舞明 ーX線消化管検査用体位变換装置とノン・クロスバー車椅子一}

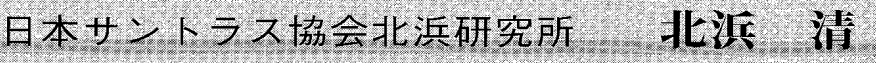

\section{1. はじめに}

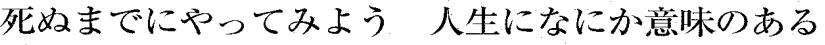
ことを わたしたちは賢者でも偉人でもない できる ことを精一杯やるだけ

—レナード・バーンスタイン,「キャンディド」より—-

\section{私は官公立病院に診療放射線技師として35年間勤務} し，定年退職後の15年間に，身体不自由者の使用を目 的にした「X線消化管検査用体位変換装置」と「ノン。 クロスバー車椅子」を発明した。前者は身体不自由者 が自力によらず体位変換できる既設X線透視台上に付 設使用する身体回転装置であり，後者は生活上欠くこ とのできない各種の移乗とトイレ使用の機能を備えた 車椅子である1)。両装置の試作は完了したが，国内専 業企業の採用に至らず，発明の商品化は極めて困難で あった。而発明は国連(ウィーン)に無償技術供与し， 目下，国連バニアン基金(パリ)で事業化中である。こ 机ら 2 装置の概要と試作経過について述べたい。

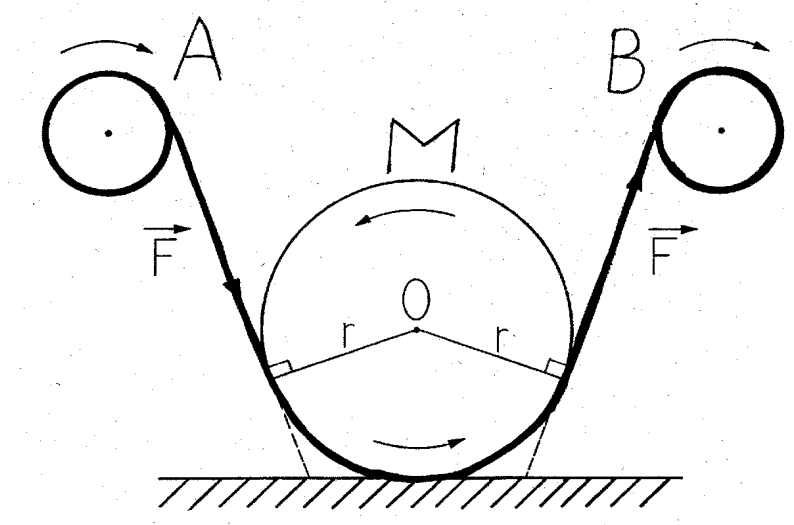

Fig. 1

\section{X線消化管検㸖用体位变換装置2)}

2-1 基本となる「物体の回転の原理」

2 個の軸受けによる回転作用はシート上の大きな物 体に接続方向の力 $\overrightarrow{\mathrm{F}}$ をえる。

物体の動径を $\overrightarrow{\mathrm{r}}$ とすれば, 力 $\overrightarrow{\mathrm{F}}$ のモーメントは, $\overrightarrow{\mathrm{F}} \times \overrightarrow{\mathrm{r}}$ で表される(Fig.1).

\section{2-2 簡単な実験}

タオルのなかほどにウイスキーボトルをねかせ，夕 オルの両端を交互に上下するとボトルが左右に回転す る。

ボトルを人体，タオルを巻とり移動シートに置き換 えたものが，装置の基本である(Fig.2).

\section{2-3 装置の構成}

Fig.3において，一対の平行回転管が透視撮影台上 約 $20 \mathrm{~cm}$ の位置に軸受で支持され，同回転管に厚み $2 \mathrm{~mm}$ の透明性ビニールシートを架け渡し巻いてある。

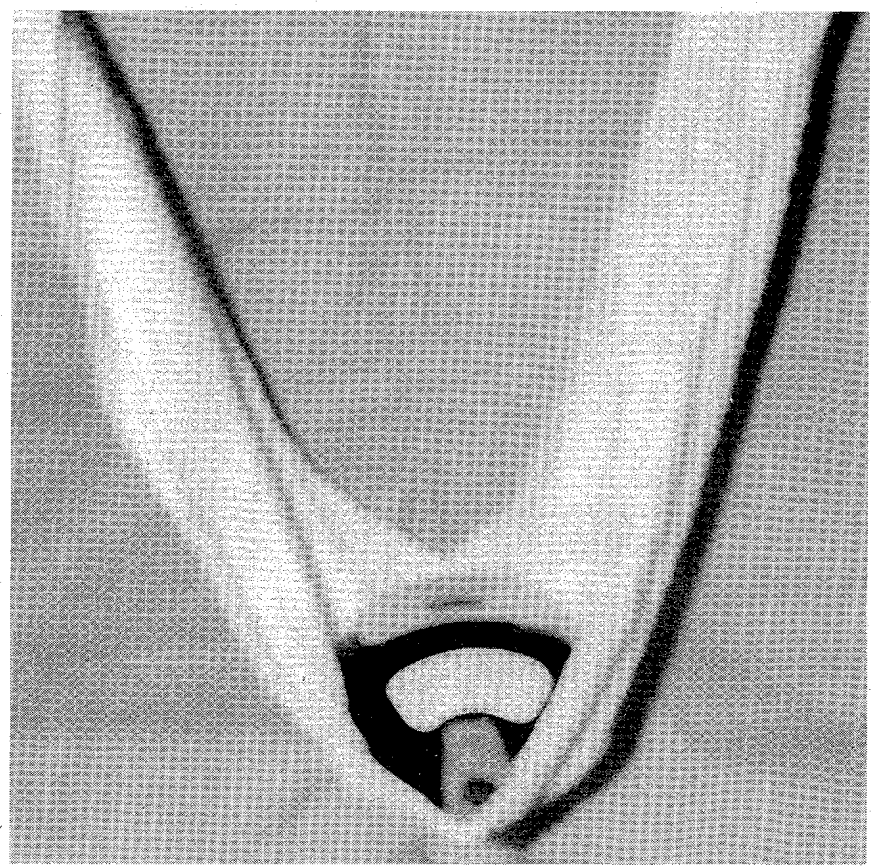

Fig. 2 
シートは中央部が天板に接するように湾曲状態におか れ，平行回転管の回転で左右に移動する。透視撮影装 置の足台をモータ，スプロケット，チェーン，軸受な どを収めた装置の動力ボックスで構成した。

本装置はフレームの脚を既設起倒式X線透視装置の 足台取付溝に挿入固定して使用する. Fig.4，5 に本装
置の配置状態を示す。

\section{2-4 装置の使用}

Fig.6，7 に試作装置の使用状況を示す。被検者は, 両手を頭部または腹部に置き，ただシートの動きに身 を任せていればよい，技師の遠隔操作により容易に体

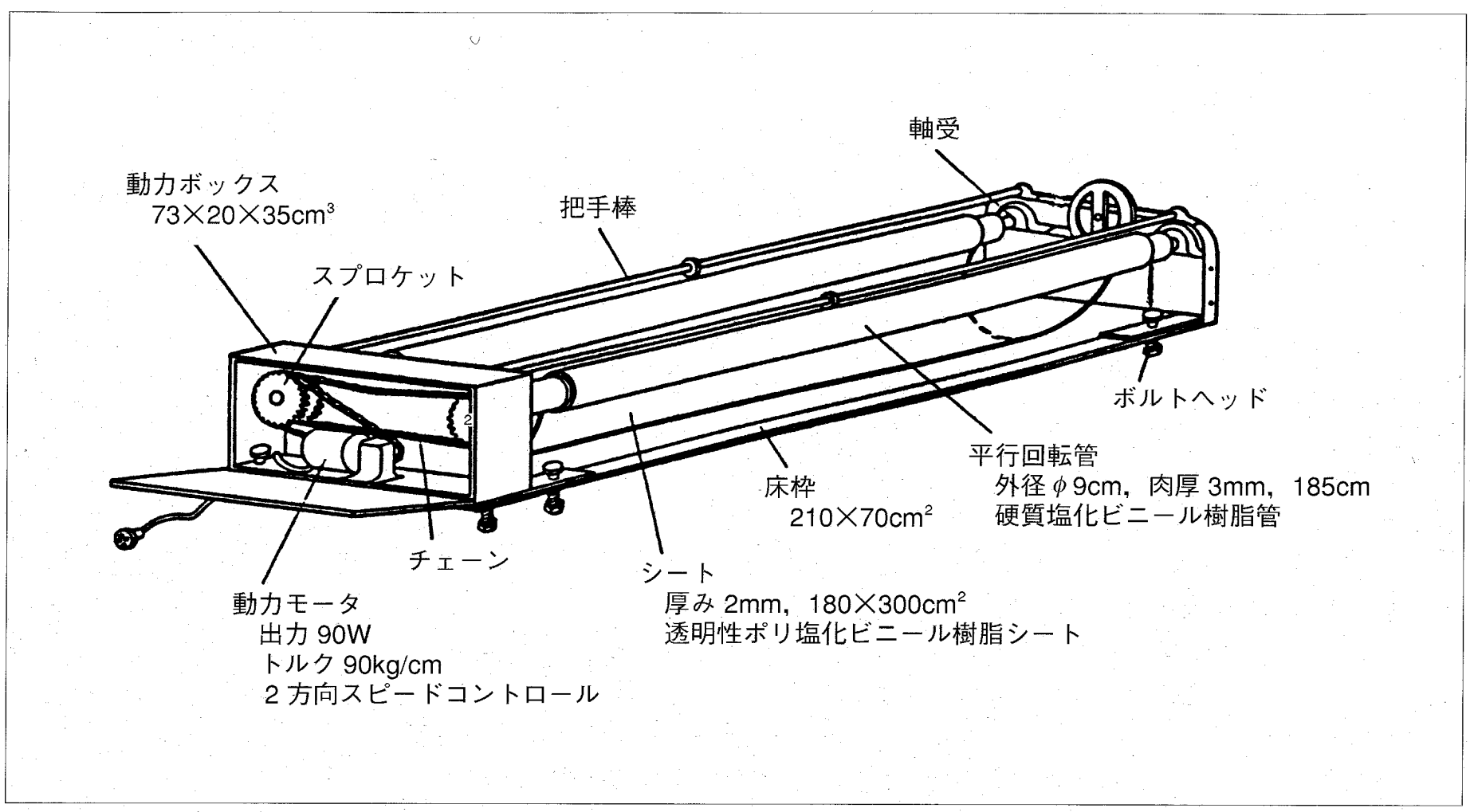

Fig. 3 試作装置の構成図

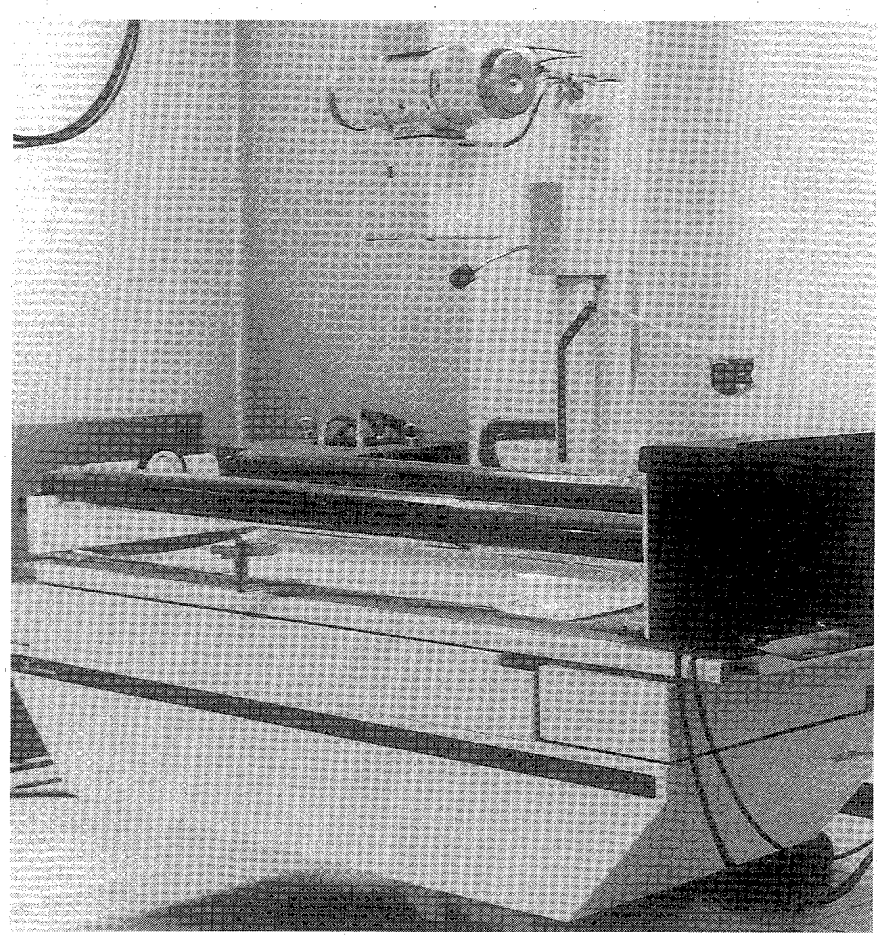

Fig. 4 装置の配置状況(オーバーチューブ型透視台)

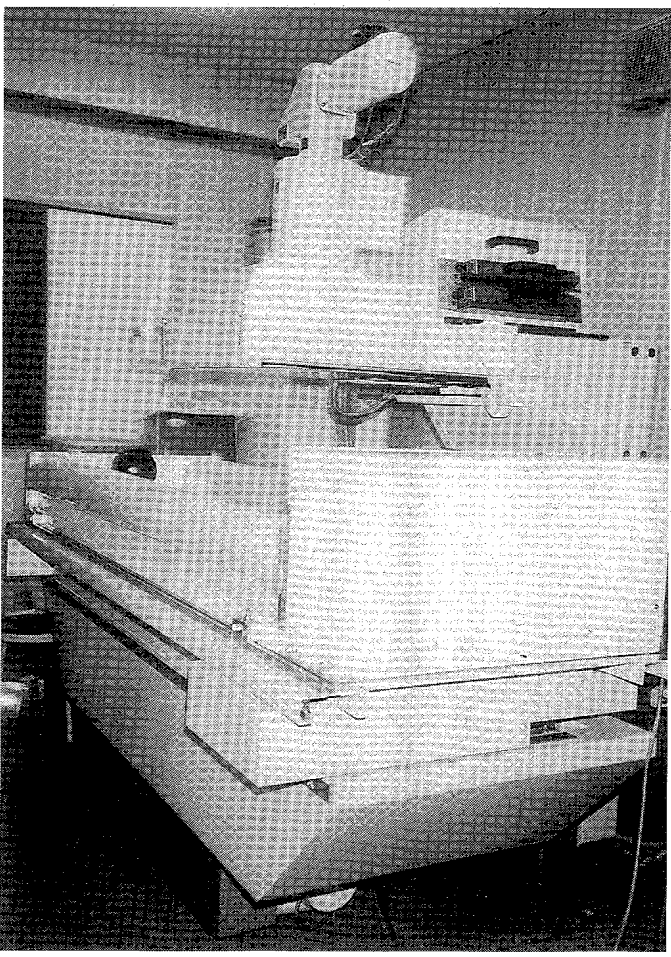

Fig. 5 装置の配置状況(アンダーチューブ型透 視台） 

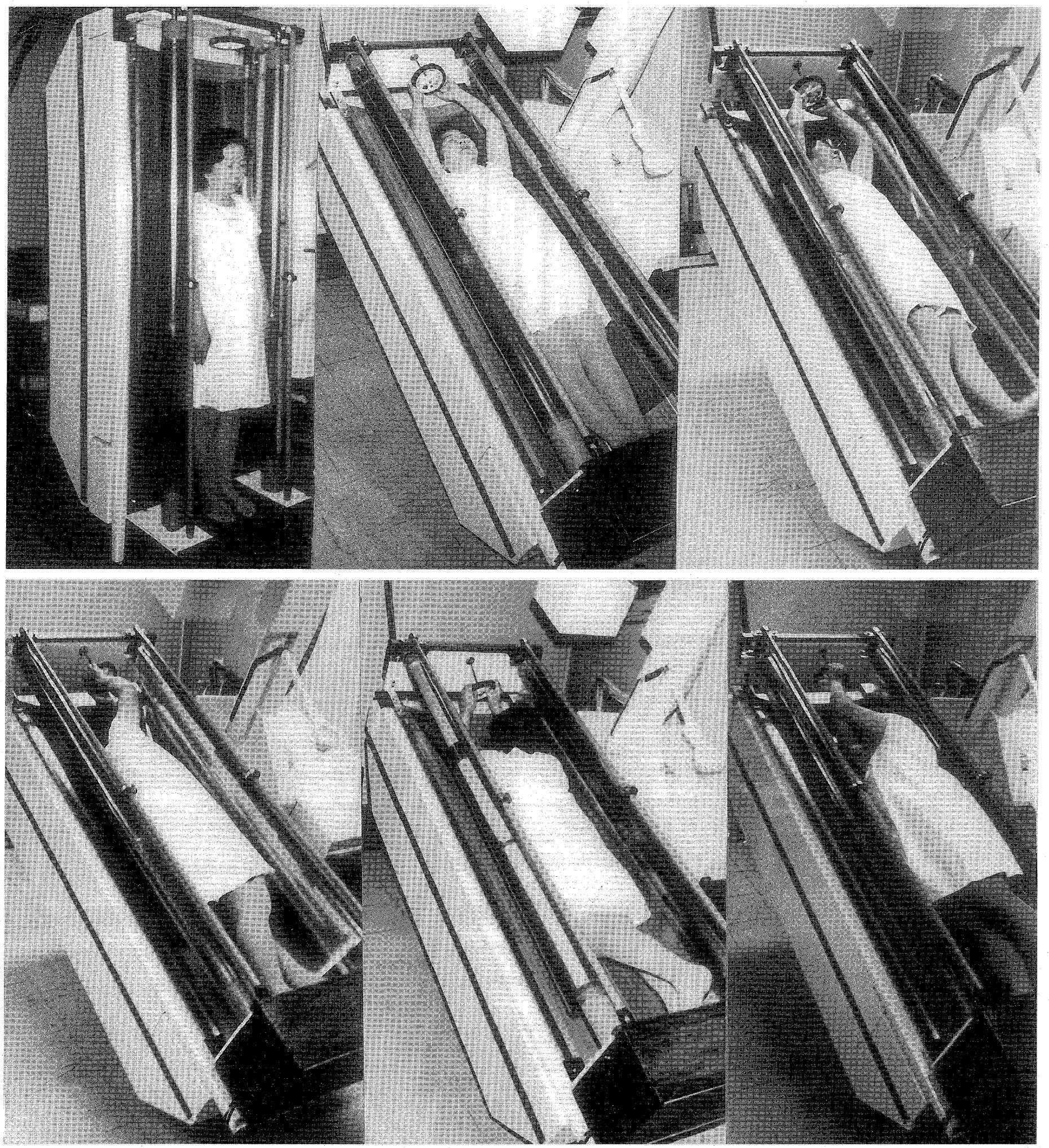

Fig. 6 装置の使用状況

$$
\begin{aligned}
& 1 \rightarrow 2 \rightarrow 3 \\
& 4 \rightarrow 5 \rightarrow 6
\end{aligned}
$$

位変換する。必要な角度で静止し，再現性ある体位を つくることができる。身体は湾曲状シート内に収容さ れ，透視台から転落の控それがない，看護者は台から 離れていられるのでX線被曝が防止される，圧迫法， 注腸操作に支障がない.

\section{2-5 考 察}

従来，X線消化管検査を目的にした体位変換装置 は，被検者をX線天板上に巾広ベルクロテープで固定 して天板と共に身体を回転するジャイロ装置3)，また 凹面状透視台が左右に30度程度ローリングして体位変 


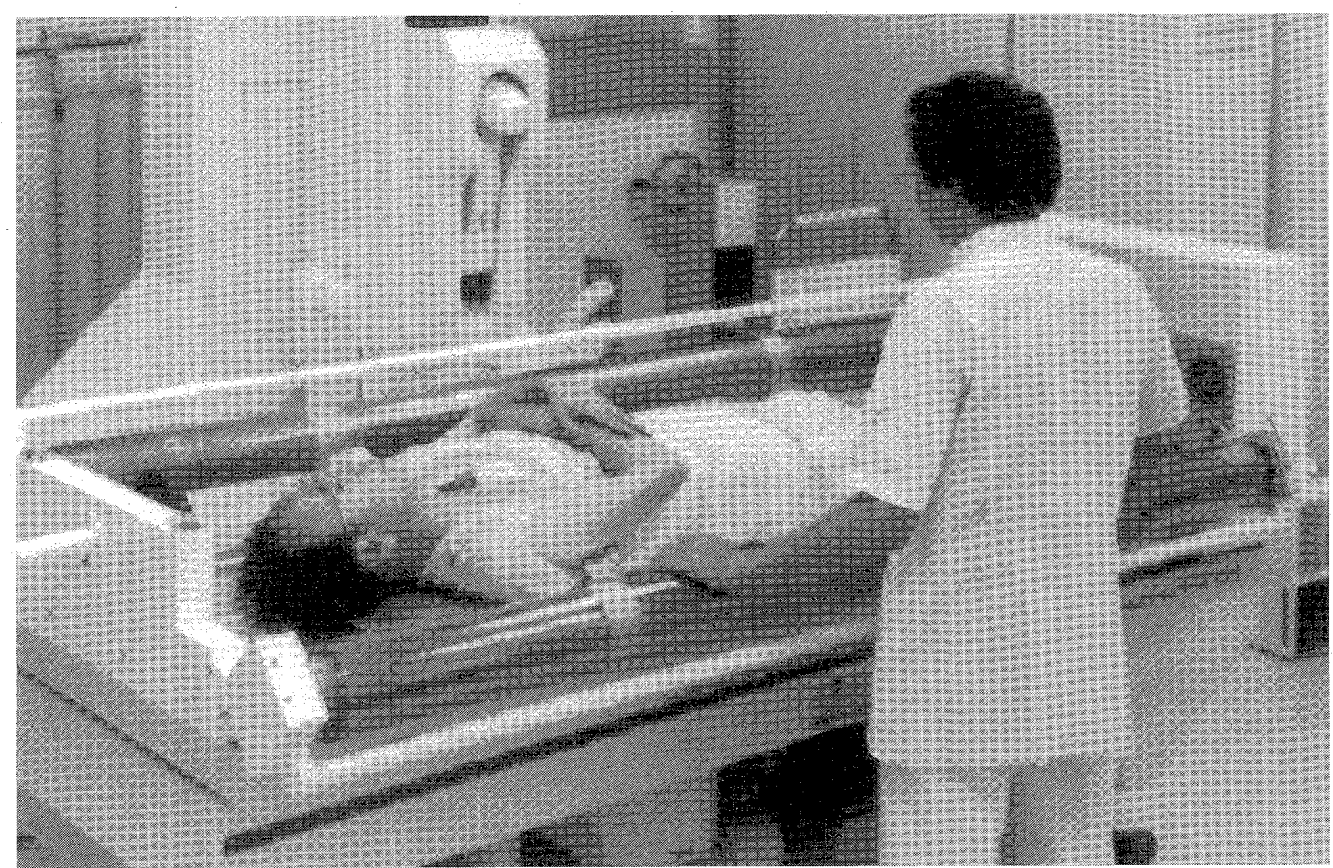

Fig. 7 装置の使用状況(平行回転管の一側は台上におろしてある)

換する胃集検用装置4がある。

しかし，前者は身体を天板に束縛して天板を自在に 回転して体位変換する大型透視撮影装置であり，被検 者に攸しい肉体的精神的な負担を与え，また，後者は 背腹腹背の体位変換時に被検者の自力動作を必要とす るなど，身体不自由者の使用には大きな難点があっ た.

これらに対比して，本装置は既設X線透視撮影台に アダプタとして取り付け使用する簡易装置であり，被 検者はただシート上に㾸ていれば自力を要せず安全か つ速やかに体位変換する。本装置の身体回転機能と, 既設透視台の起倒抢よび天板の上下左右へのスライド 機構との三者組み合わせ使用により，高齢者，身体障
害者(視覚障害者を含む)の三次元的X線検査が安全に 実施できる。なお，1970年代，シーメンス社が透視 撮影台に沿ってベルトを回転する「ロータシリンダ装 置」5)を販売したが，本発明のシート湾曲駆動機構は， より単純で効率的である。

Fig.8，9は，本発明の身体回転機構をベッド，スト レッチャに適用したもので，患者の移動，移乗，体位 変換の介助作業，また術後重症者の身体摇動治療など を容易にする。

\section{2-6 小 括}

既設起倒式X線透視撮影台に取り付け使用する消化 管検査用身体回転装置を発明・試作し，その臨床効果

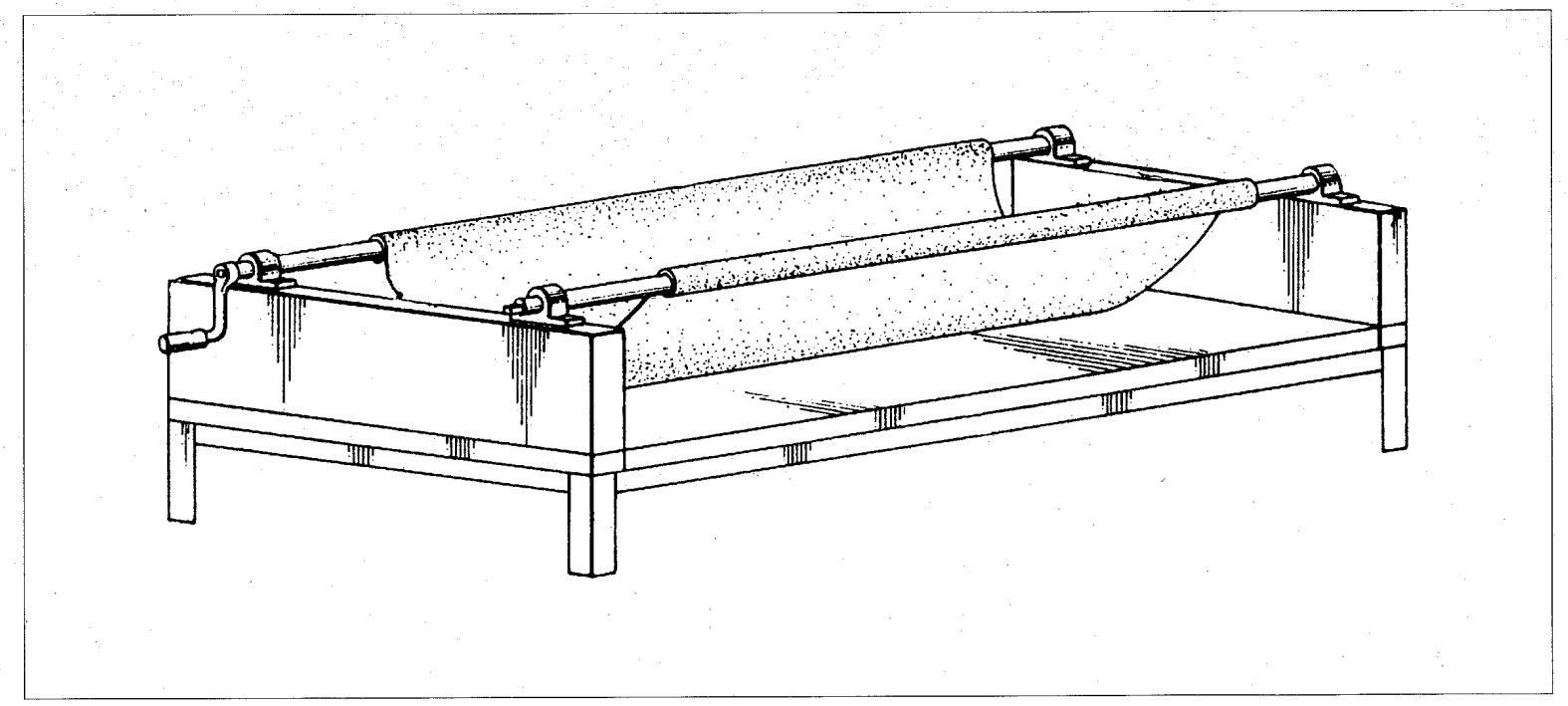

Fig. 8 ベッドへの適用図(身体回転手動) 


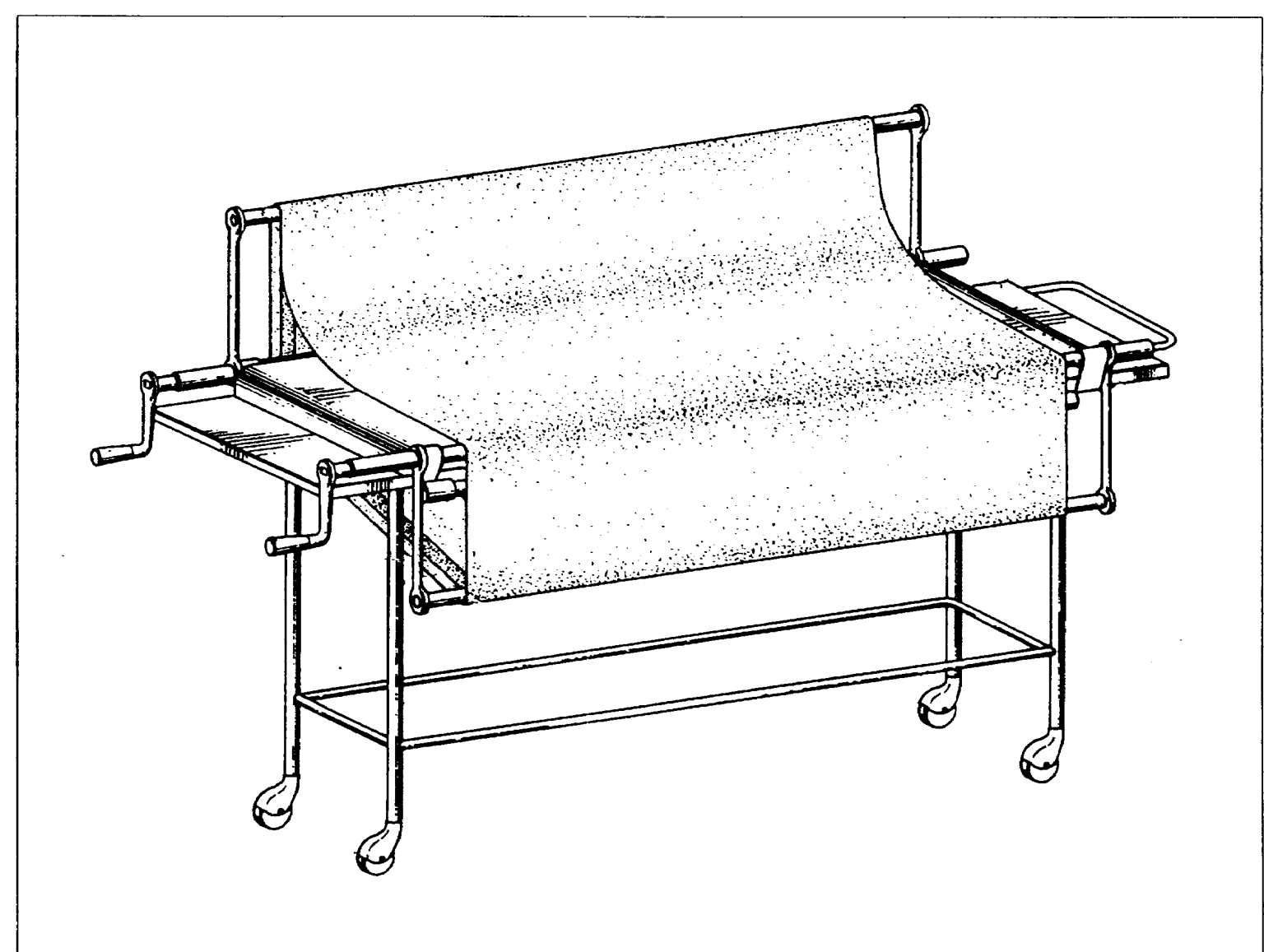

Fig. 9 ストレッチャへの適用図(身体回転手動)

を確かめた．本装置によれば身体活動不自由な高齡 者, 身体障害者の体位变換を容易かつ安全に行うこと ができる。

\section{3. ノン・クロスハー一車椅子6)}

今日の世界の標準型車椅子》1 は1933年米国E\&J社の 発明によるもので，すでに半世紀余にわたり，広く使 用されている。この車椅子は，座席の下に車体折りた たみ用のクロスバー(交差支柱)を備えていることが特 長である。

この標準車椅子は車体が折りたためるので輸送と保 管に極めて便利である。しかし，車椅子使用者にとっ ては日常生活に欠くことのできないトイレ，シャワー の使用をはじめ，各種のトランスファー作業が容易に できない難点をもっている。これらを行う際には，し ばしば腰椎症を引き起こす介護者の抱きかかえ作業, あるいは，機械操作に習練を要するリフト装置の使用 などを必要とする，この問題を解消するため，新たな 車椅子を発明した。

本発明のノン・クロスバー車椅子をFig.10，11に示 す。手動用ハンドリムつき車輪は簡単に取りはずせ， これを介助車として使用できる。また，安楽性の良い 常用座席とトイレ，シャワー用座席との交換使用が容 易である。

\section{3-1 構造の基本}

金属製パイプ椅子(Fig.12)の背当支柱を点線で切断 し，着脱可能にした。この切断部および横手支持の固 定を確実にすれば，椅子の安定性は極めて高いことが 理解される。

\section{3-2 車体の構成}

Fig.13，14に示すように，本発明のノン・クロスバ 一車椅子は，略コの字状に並立する主支柱に，背当支 柱と前部支柱が横手連結する．背当支柱と座席は車体 に着脱する，座席は时支柱から下げたバンドに接続し て支持され，座席の下部にはなにも設けず後方に開放 している．車体の構成は単純でコンパクト化が容易で ある。

\section{3-3 座席の昇降技術}

本車椅子に新たな座席昇降方法を使用した。Fig.15， 16に示すように，車椅子の时支柱に平行してハンドル つき管体を設けてある．时支柱を軸としてハンドルを 外側に 180 度回転すると，吊り座席は女性の力でも容 易に80 kgの身体を載せて昇降する．物体の「回転の原 理」を応用した技術である。この操作により，車椅子 の座席はベッドから $2 \sim 3 \mathrm{~cm}$ 浮き上がるので, 簡単に 車椅子をべッドに出し入れすることができる，車椅 


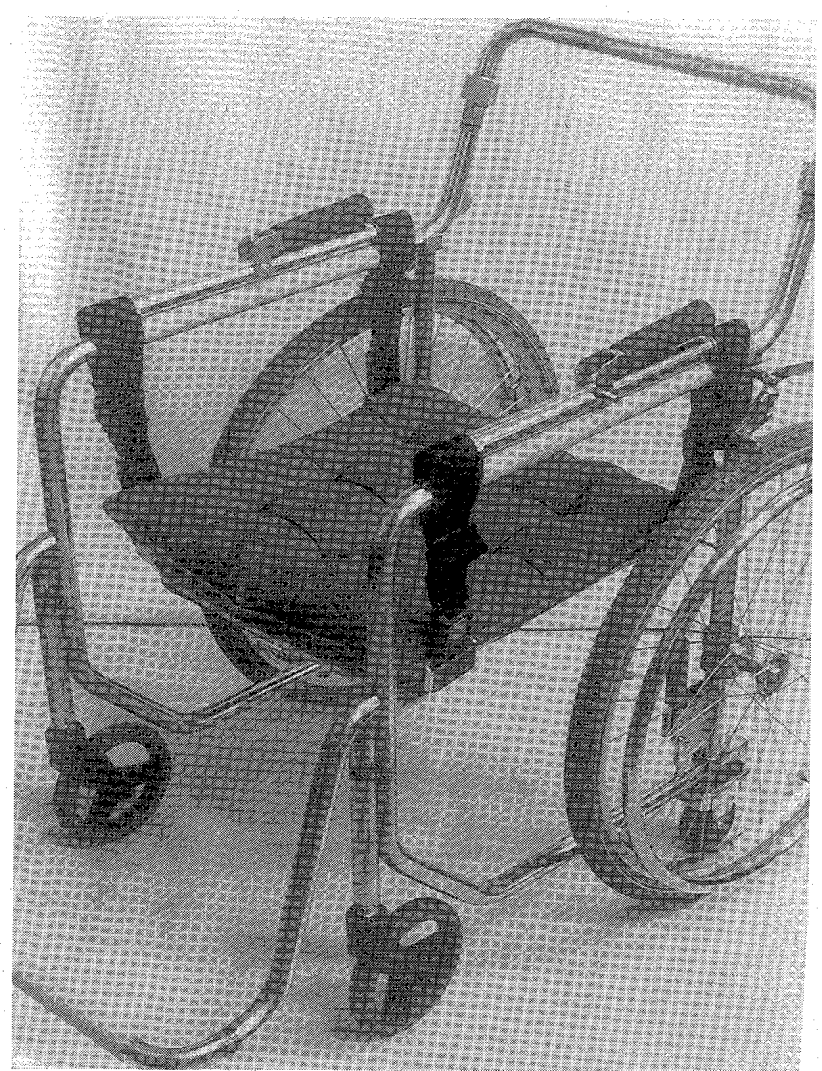

Fig. 10 ノン・クロスバー車椅子(自走型)

子，リフト装置に扮ける座席昇降方法は，電動モー 夕，油圧シリンダなどの動力を使用するため，装置が 堅牢重量化したこれに対比して，本法は著しく簡単 な方法で，シンプルで軽量な車椅子の製作に卓効があ る。

\section{3-4 使用方法}

ベッドから車椅子へのトランスファの一例をFig.17 について説明する。

まず「ノン・クロスバー車椅子」のハンドリム車輪を 取りはずし「介助車」にする。

1）座席をべッドに置き，これに腰を扔ろす。

2)背当をはずし，車体を後部からベッドに挿入す る.

3）座席に吊りベルトを接続し，背当を付ける。

4) ハンドルを 180 度外側上方に回転する(ベッドか ら座席が浮き上がる)。

5) 車体をベッドから引き出す(トランスファが完 了).

上記と逆の順序で，介助車からベッドへのトランス ファを行うことができる.

\section{3-5 考 察}

本車椅子は車椅子それ自体にトイレ・トランスファ の機能を備えた新たな車椅子である，家庭内での使用

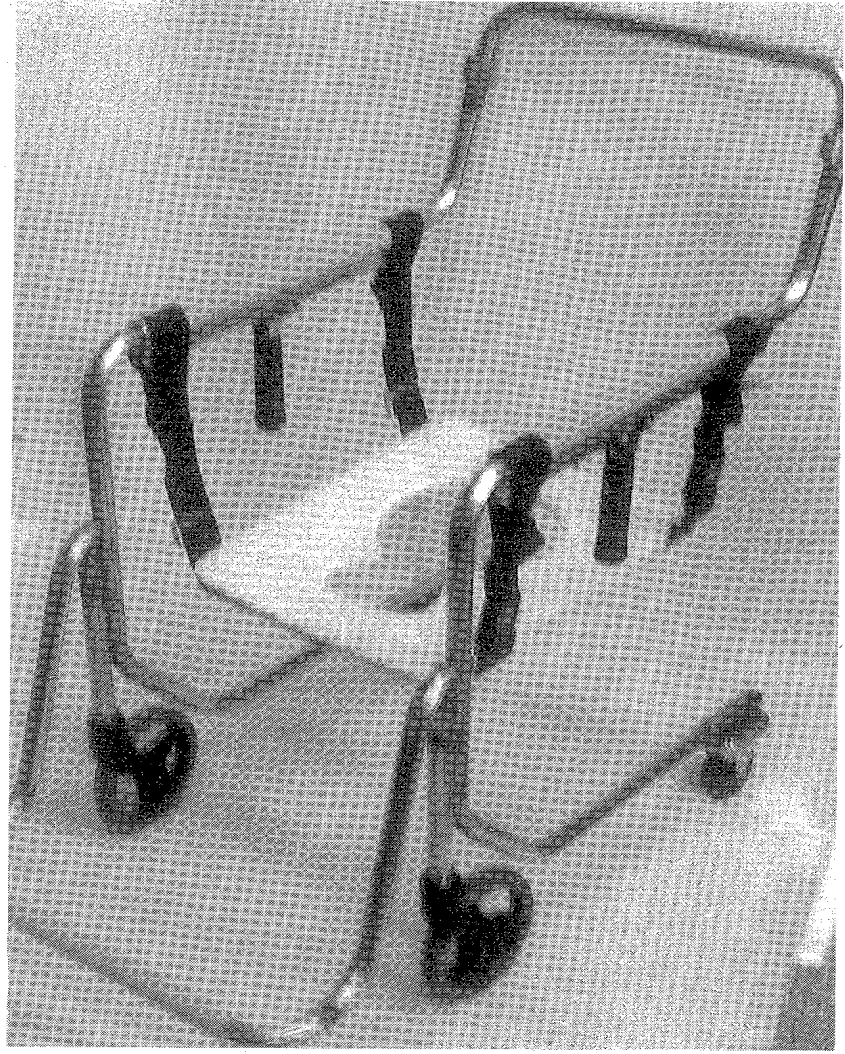

Fig. 11 ノン・クロスバー車椅子(介助型)

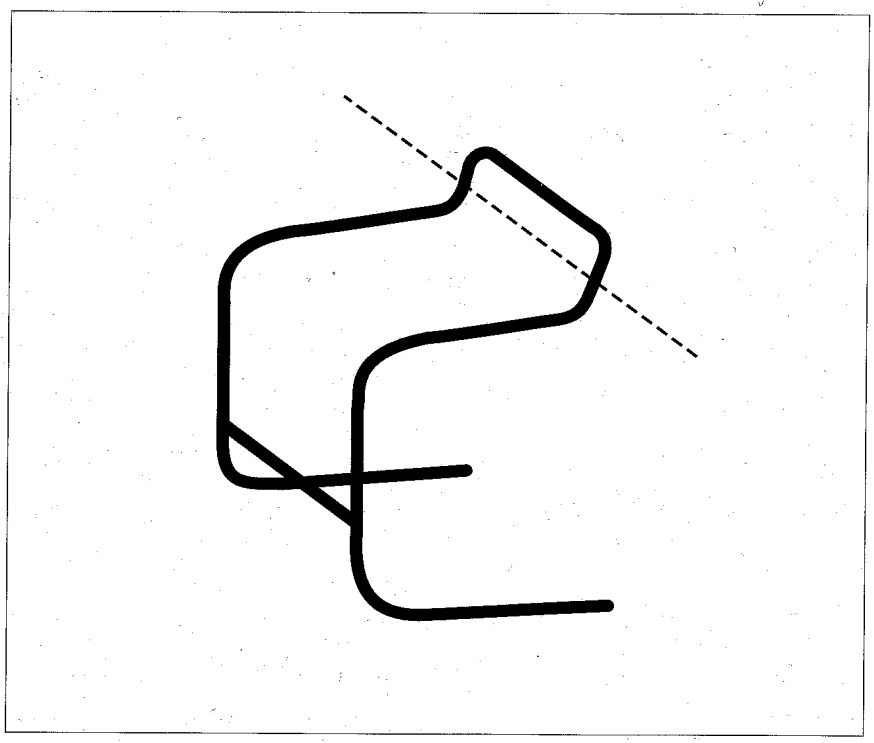

Fig. 12 ノン・クロスバー車椅子(構造の基本)

はもとより, 学校, 職場, 旅行 (自動車・列車・航空 機の座席)など広い社会生活の場に㧈けるトイレ使用 と各種のトランスファ作業が容易になる。身体不自由 者の自立を支援し，介護者の介助負担を軽減する。ま た，多くの症例において健常者用トイレの兼用が可能 になる。 


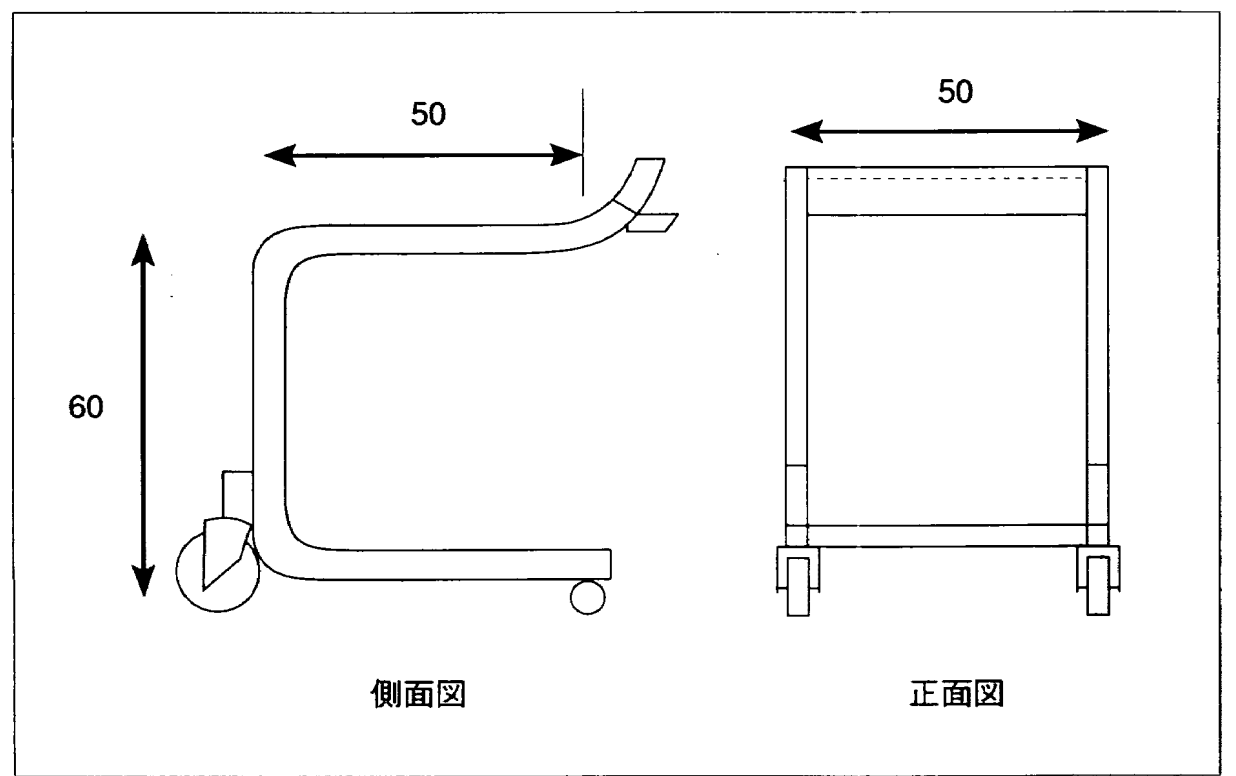

Fig. 13 ノン・クロスバー車椅子(支柱のサイズ 単位 $: \mathrm{cm}$ )

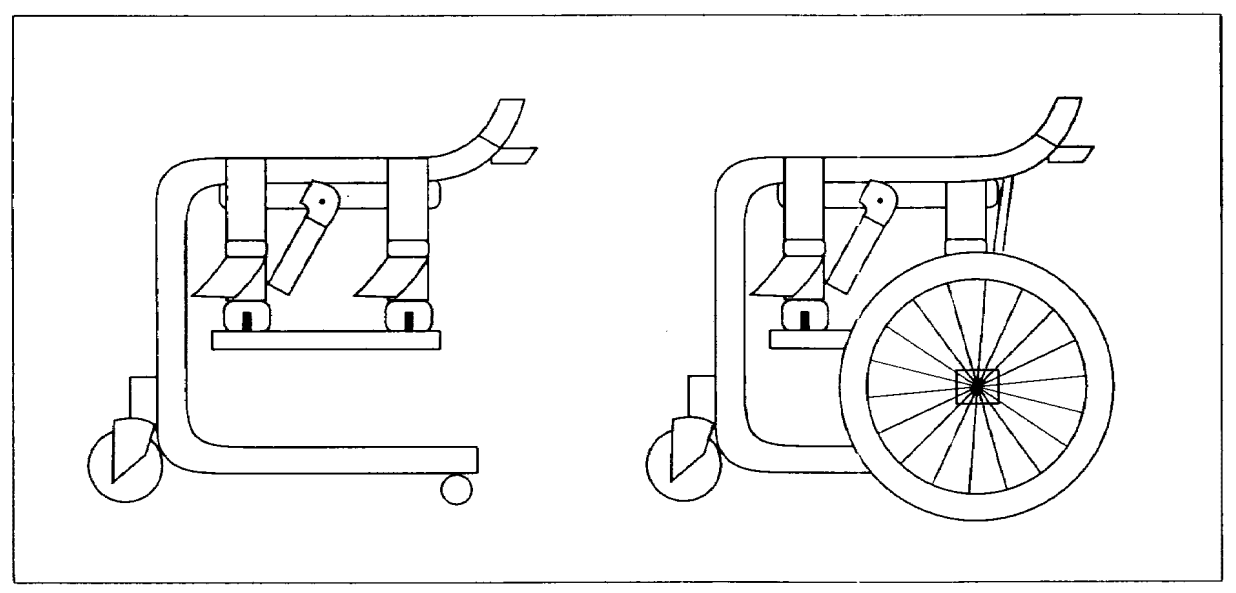

Fig. 14 ノン・クロスバー車椅子(ハンドリム付き車輪は容易に着脱する)

\section{3-6 小 括}

車椅子それ自体にトランス ファ機能をもつ新たな車椅子 を発明・試作してその効果を 確認した.ノン・クロスバー 車椅子は身体活動不自由な高 齢者, 障害者の日常生活に使 用でき，自立を支援し，介護 者の介助負担を軽隇する。

\section{4. 舟体不自由曺のためのX

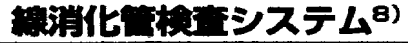

すでに述べた「X線消化管検 查用体位変換装置」と「ノン。 クロスバー車椅子」の二発明を 連携使用するX線消化管検查 システムの説明図をFig.20に 示す．身体回転装置付きス卜 レッチャの利用も考えられ る。医療検查に扮けるノーマ ライゼーションである。

\section{5. 笔明私和}

診療放射線技師の発明は医 療機器の創作である。この研 究には，独創性の確保に学術 論文または特許を必要とす る．学会発表または特許出願 がその一里塚で，二発明はそ れらの手続きを踏襲した。発

明は一課題に専心して少なくとも5 年の歳月

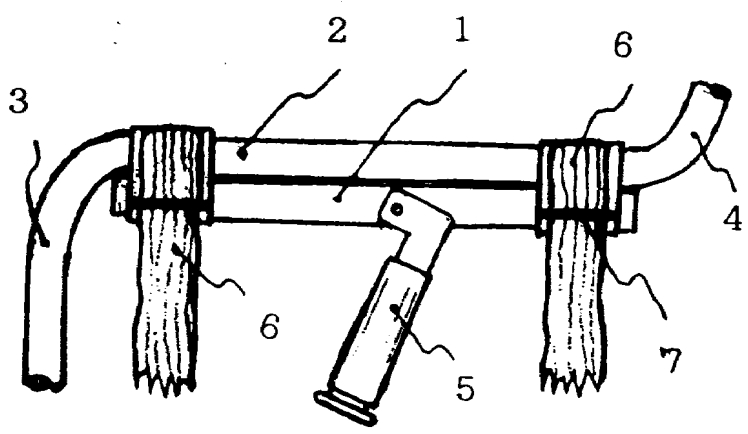

Fig. 15 座席の年降機構図(管体を时支柱を軸に外側へ180度回転する と容易に座席が界降する)

$\begin{array}{ll}1 & \text { 管体 } \\ 2 & \text { 时支柱 } \\ 3 & \text { 前部支柱 } \\ 4 & \text { 背当支柱 } \\ 5 & \text { ヘンドル } \\ 6 & \text { 吊りベルト } \\ 7 & \text { ベルトのガイド }\end{array}$

を要する技術研究と考える。この間において 毎年開催される技術学会，また 4 年ごとの国 際放射線技術会議などは，あえて期限を設定 し切迫感をもって仕事をまとめるような発明 家の努力目標として格好な機会であった。発 明は，これらの積み重ねのなかで，時には 「忍術をもつかって不可能を可能とし」また， 予期しない発想に試作の犋状を助けられたり して「実現の可能性を確認できた時点で終了す る $\rfloor^{9)}$.

二発明は，1984年試作の当初から科学技術 庁新技術事業団が国内の関連機器会社に商品 化交渉を行ったが，採用されるに至らなかっ た。これらの経過から, 個人発明は関連企業 の既成方針を変革することから，企業にとっ て敵対の立場にあることを知った。わが国に おいて該関連企業が診療放射線技師の発明を 


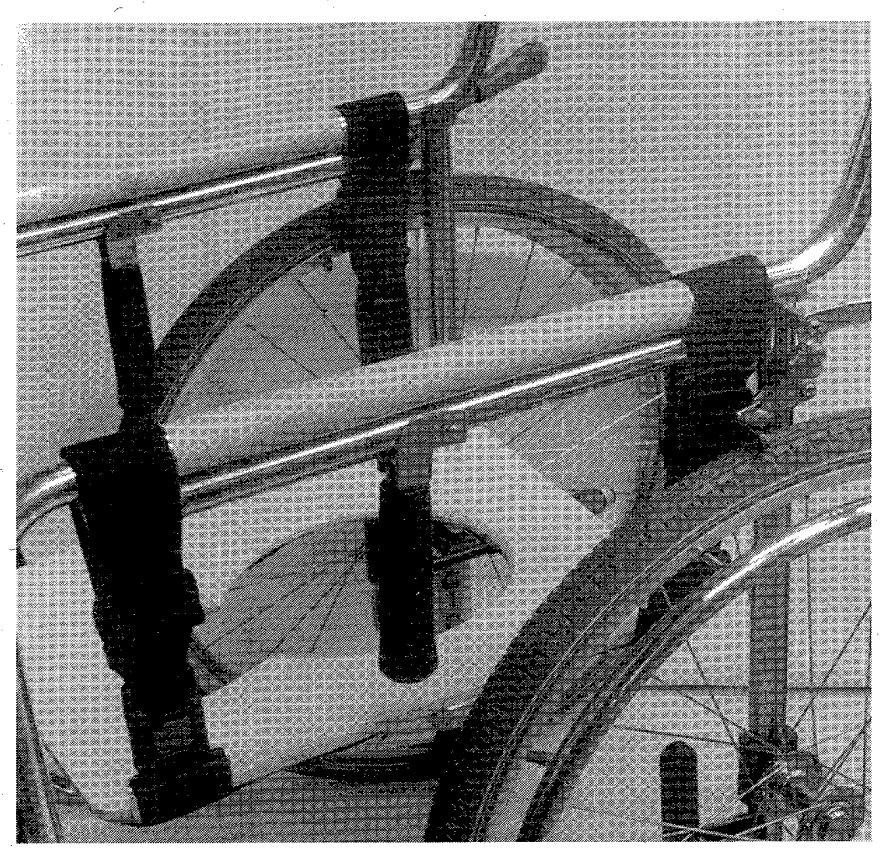

Fig. 16 座席の昇降機構

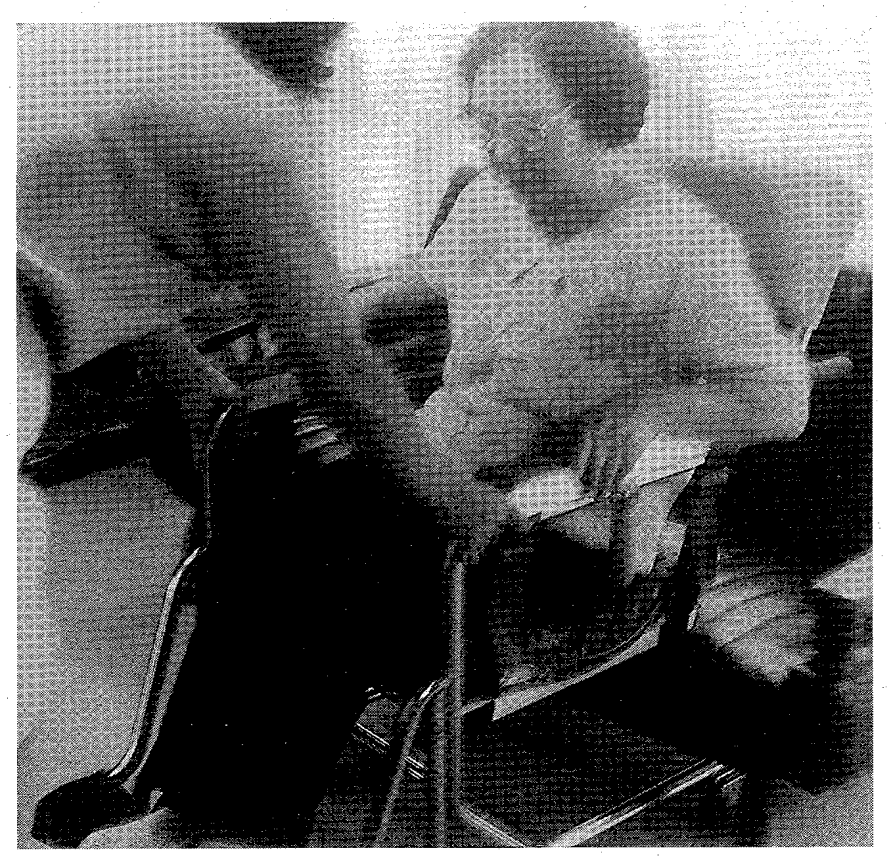

Fig. 18 ソファへのトランスファ

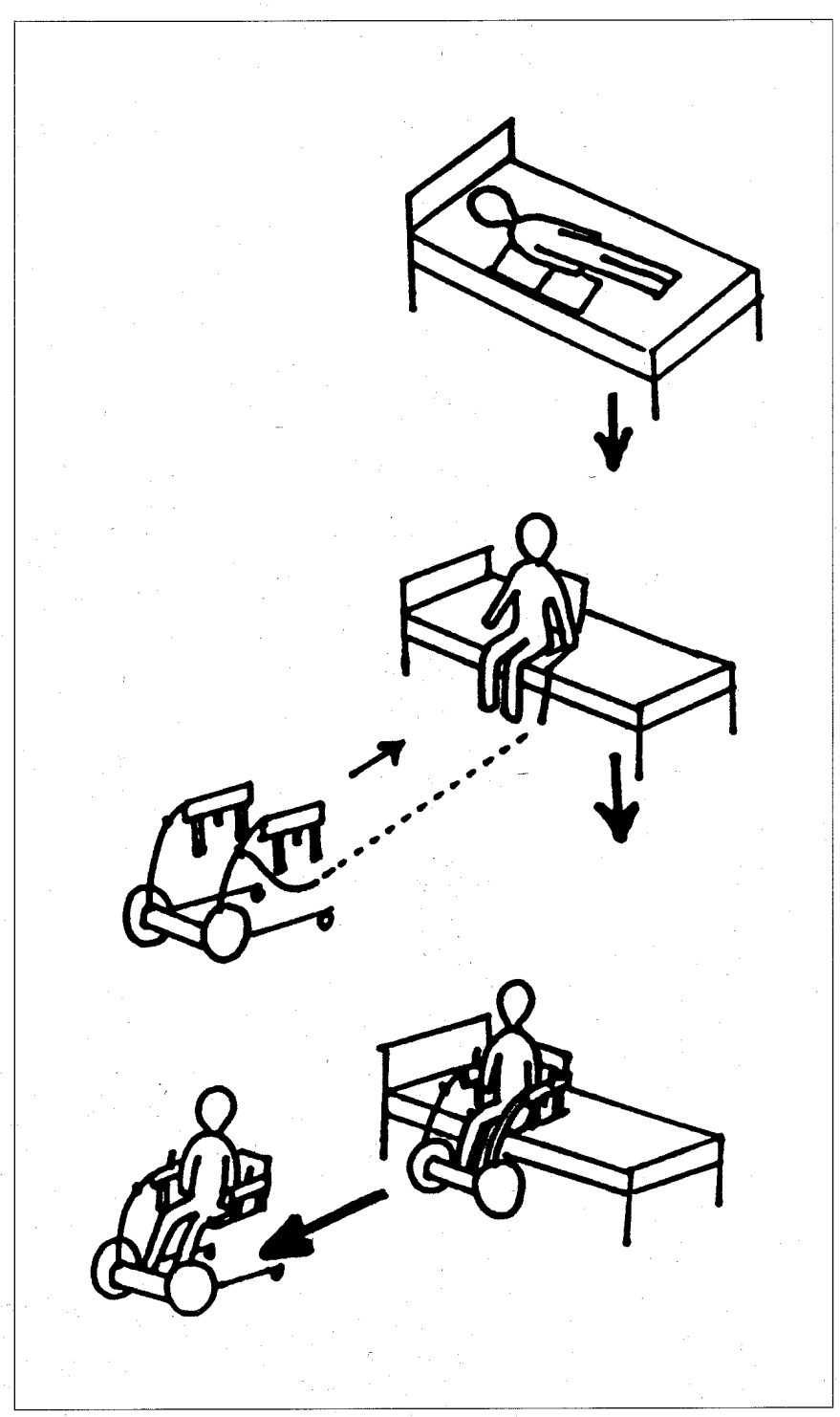

Fig. 17 ベッドから車椅子へのトランスファ

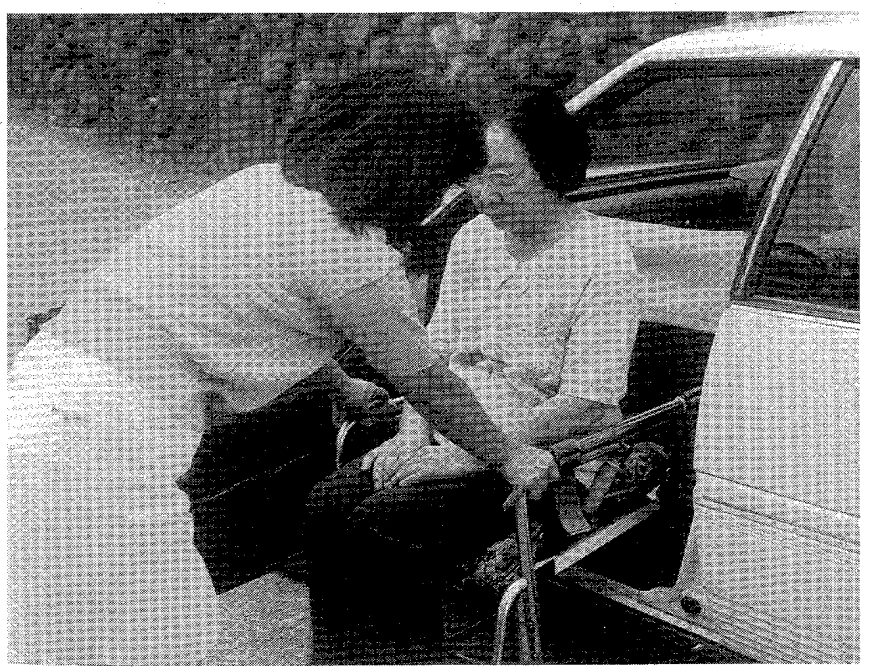

Fig. 19 自動車へのトランスファ 
採用することは極めて困難と考える。

もとより発明が容易に企業化されないことは巷間発 明史のよく記すところである。哲学，芸術，科学など の独創的成果の多くが社会に受け入れられないこと は，変革を拒み現状維持を望む人間心理の自然な現れ で，発明もまたその例外でないとの確固とした認識が 必要である。

ちなみに，開発と商品化は利益を目的とする企業の 経済的技術活動で，これらは発明とは異質な事業であ る。日本はもつぱら科学先進国の発明図面を基に開発 商品化を進展し，巧みな後追い技術の流れにのって今 日の経済大国に成長している。

\section{6. 二発明その後}

幸いにも1991年，国際高龄者の日を記念した日本ウ
エルエーング協会 (日本WHO理事，吉田壽三郎) 第 1 回発明展において，ノン・クロスバー車椅子に厚生大 臣賞が与えられ，これが機縁で二発明を国連(ウィー ン）に無償技術供与した。目下，両装置は国連管轄バ ニアン基金(パリ)に拈いて製品化計画中である。ここ において一診療放射線技師による二発明の目的は達成 した。

\section{7. おわりに}

一診療放射線技師が定年退職後に行った二発明につ いて述べた。装置の試作は完了し，社会がこれらを必 要とする時はいつでも利用できる，発明は生き甲斐で あった。それゆえ今日，私は高齢化時代に生きたお陰 で扮のずから身についた発明ノウハウをさらに生かし て，次の新たな発明への挑戦を考えている.

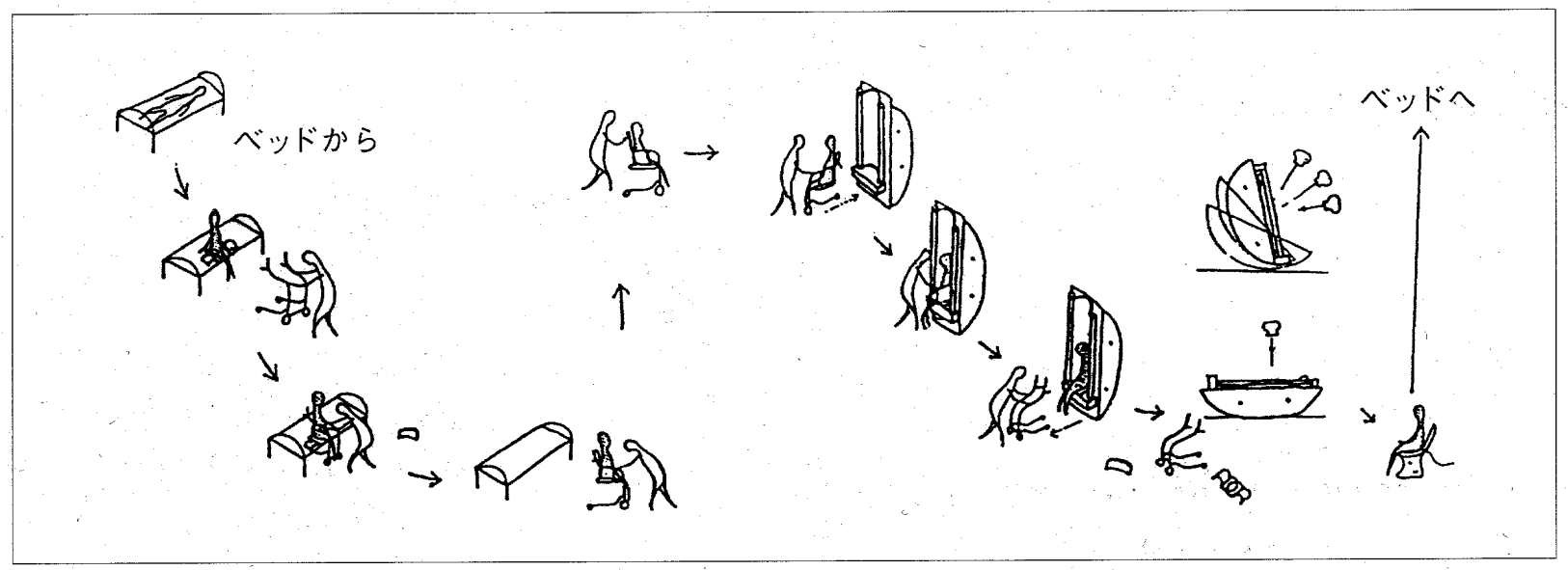

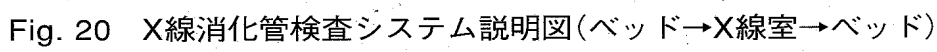

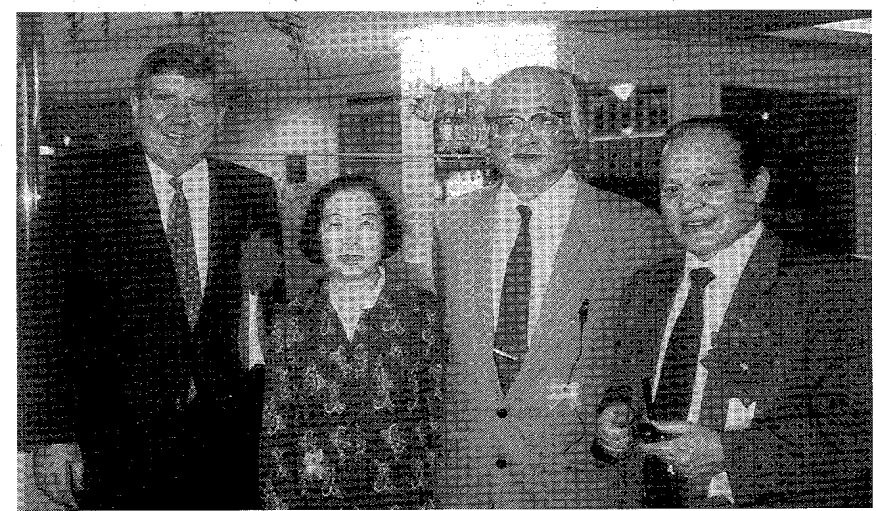

Fig. 21 筆者近影

国連バニアン基金理事長 エベラルド・コンプトン 氏 (写真左)

国連社会開発センター次長 モハメット・シャリフ 氏(写真右)

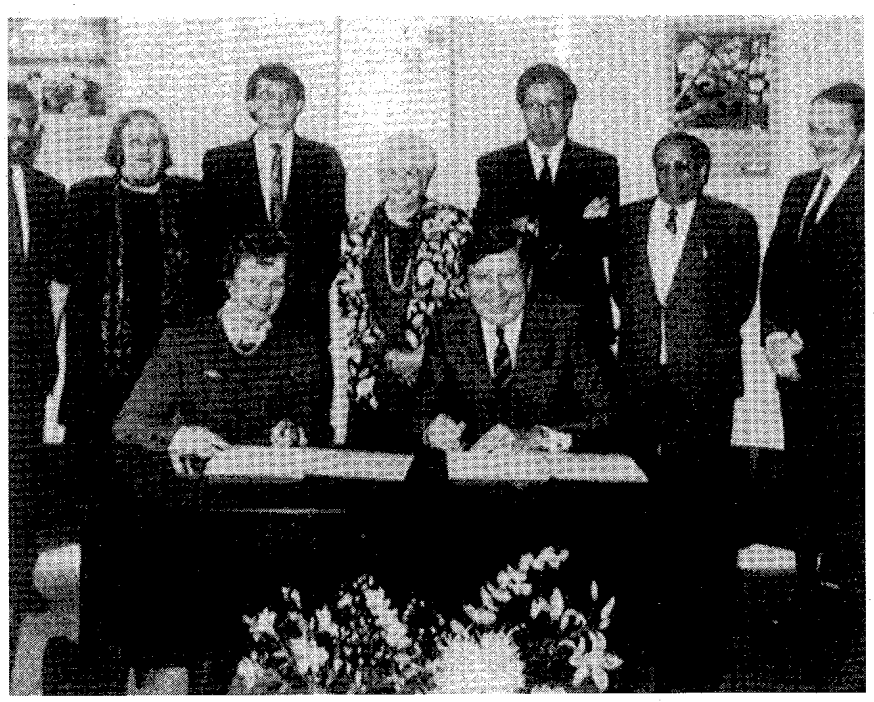

Fig. 22 Margaret Anstee, UN Under-Secretary-General, and Everald Compton, President, Banyan Fund signing relationship agreement. 


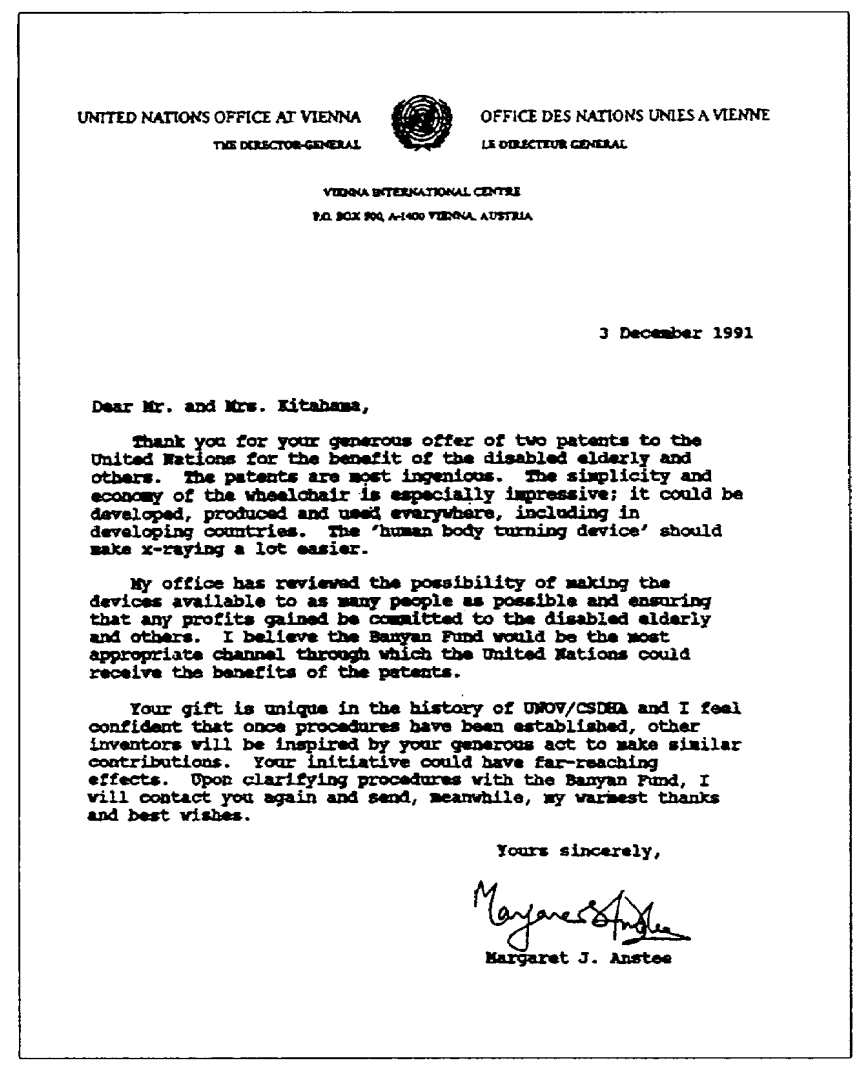

Fig. 23 国連からの手紙(1)
UNITED NATIONS OFFCE AT VIENANA OFFICE DES NATIONS UNIES A VENNE

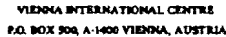

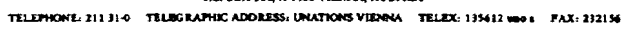

$$
1 \text { July } 1992
$$

Dear Mr. and Mrs. Kitahama,

Further to Miss Margaret J. Anstee's letter of 3 Deceuber 1991 , generous offer of to patents to the United kat ions for the benefit of the disabied elderiy.

After consulting with ine United Mations Legal office, both in Fiennd and her York, have learned that the simplest way for us to process your gift, is to transfer the patents to the banyan fund
Association:

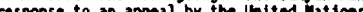

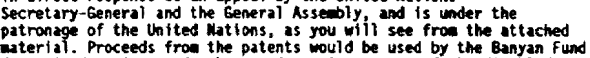
aterial. Proceeds fron the patents would be used by the banyan fund elderly in developing countries. With your kind peris ission,
therefore, re would ike to transfer the patents to the Banyan fund I look forward to hearing your views on the project and take
this opportunity to express our warmest greetings as well as
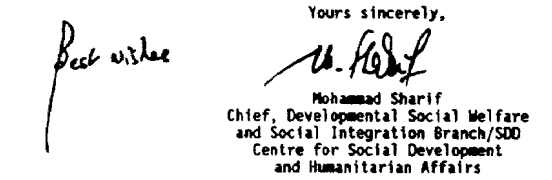

Mr. and Mrs. Kitahame Tsukut-gun, Kanagiat

Fig. 24 国連からの手紙(2)

「特許」X線消化管検査用体位変換装置 日本1406319，独国3438956， 英国2151472.

$$
\begin{gathered}
\text { ノン・クロスバー車椅子 } \\
\text { 日本1768101, ほか. } \\
\text { 米国(関連特許出願中). }
\end{gathered}
$$

$$
\text { SO } 917 / 13 \quad 29 \text { actober } 1992
$$

Dear Wr. and Ars. Kitahon,

Thank you for your letter of 11 september 1992 rogarding the transfer of your patents,

1 - pleased to advise you that, in accordance with your 1 a pleased to advise you that, in accordance with your Association, for furtinar action.

May 1 take this opportinity to express, once agaln wo dop appreclatelon for your gemeroes of fer and wish you will

Yours sincerely.

$$
\begin{aligned}
& \text { L R Sokaturi } \\
& \text { Mearyt. Sotal ski }
\end{aligned}
$$
antre for Social Developent

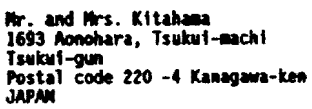

Fig. 25 国連からの手紙(3) 


\section{参考文献}

1) 全国放射楾技師総合学術大会抄録集 : (1994).

2) 第 8 回国際放射線技術会議 (米国ホノルル)論文集 : (1985).

3）黑川利雄，斎藤達雄，西山正治，他：回転多方向撮影X線 テレビ装置. 日本医放会誌，34(11)，788-800，(1974).

4）シーメンス，東芝，他：「商品カタログ」（1980１990）。

5)シーメンス：商品カタログ「ローターシリンダー装置」 (1970 1980).

6) 第 3９ 回日本リハビリ工学協会カンファレンス論文集： (1988 1994).

7) 大川嗣雄, 伊藤利之, 田中 理, 他：車いす。医学書院, (1987)

8）第 9 回国際放射線技術会議(仏国パリ)論文集：(1989).

9) 西掘栄三郎：西掘流新製品開発一忍術でもええでー。 日本 企画協会，（1981）. 